\title{
Overstocking dairy cows during the dry period affects dehydroepiandrosterone and cortisol secretion
}

\author{
M. Fustini, ${ }^{*}$ G. Galeati, ${ }^{* 1}$ G. Gabai,† L. E. Mammi, ${ }^{*}$ D. Bucci, ${ }^{,}$M. Baratta,ł P. A. Accorsi, ${ }^{*}$ and A. Formigoni \\ *Department of Veterinary Medical Sciences (DIMEVET), University of Bologna, 40062 Ozzano dell'Emilia (BO), Italy \\ †Department of Comparative Biomedicine and Food Science, University of Padua, 35020 Legnaro (PD), Italy \\ ‡Department of Veterinary Science, University of Turin, 10095 Grugliasco (TO), Italy
}

\begin{abstract}
Stressful situations trigger several changes such as the secretion of cortisol and dehydroepiandrosterone (DHEA) from the adrenal cortex, in response to ACTH. The aim of this study was to verify whether overstocking during the dry period (from $21 \pm 3 \mathrm{~d}$ to the expected calving until calving) affects DHEA and cortisol secretion and behavior in Holstein Friesian cows. Twenty-eight cows were randomly divided into 2 groups (14 animals each), balanced for the number of lactations, body condition score, and expected date of calving. Cows in the far-off phase of the dry period (from 60 to $21 \mathrm{~d}$ before the expected calving date) were housed together in a bedded pack. Then, animals from $21 \pm 3 \mathrm{~d}$ before the expected calving until calving were housed in pens with the same size but under different crowding conditions due to the introduction of heifers (interference animals) into the pen. The control condition (CTR) had 2 animals per pen with $12.0 \mathrm{~m}^{2}$ each, whereas the overstocked condition (OS) had 3 interference animals in the same pen with $4.8 \mathrm{~m}^{2}$ for each animal. On $\mathrm{d}-30 \pm 3,-21 \pm 3,-15 \pm 3,-10 \pm 3$, and $-5 \pm 3$ before and 10, 20, and 30 after calving, blood samples were collected from each cow for the determination of plasma DHEA and cortisol concentrations by RIA. Rumination time (min/d), activity (steps/h), lying time $(\mathrm{min} / \mathrm{d})$, and lying bouts (bouts/d) were individually recorded daily. In both groups, DHEA increased before calving and the concentration declined rapidly after parturition. Overstocking significantly increased DHEA concentration compared with the CTR group at $\mathrm{d}-10(1.79 \pm 0.09$ vs. $1.24 \pm 0.14 \mathrm{pmol} / \mathrm{mL})$, whereas an increase of cortisol was observed at $\mathrm{d}-15$ $(3.64 \pm 0.52$ vs. $1.64 \pm 0.46 \mathrm{ng} / \mathrm{mL})$. The OS group showed significantly higher activity (steps/h) compared with the CTR group. Daily lying bouts tended to be higher for the OS group compared with CTR group
\end{abstract}

Received April 8, 2016.

Accepted September 17, 2016.

${ }^{1}$ Corresponding author: giovanna.galeati@unibo.it in the first week of treatment. The overall results of this study documented that overstocking during the dry period was associated with a short-term changes in DHEA and cortisol but these hormonal modifications did not influence cow behavior.

Key words: dairy cattle, cortisol, overstocking, dehydroepiandrosterone, dry period

\section{INTRODUCTION}

Stressful situations trigger several changes such as activation of the sympathetic nervous system and hypothalamic-pituitary-adrenal axis. As a consequence, the adrenal cortex, in response to ACTH, starts to secrete both cortisol and dehydroepiandrosterone (DHEA). Cortisol and DHEA are produced in different sections of the adrenal cortex; the zona fasciculata secretes cortisol and the zona reticularis secretes DHEA and its sulfated metabolite dehydroepiandrosterone sulfate (DHEA-S; Nguyen and Conley, 2008). In female primates, DHEA and DHEA-S are also produced in the ovary (Sirinathsinghji and Mills, 1983), and in primates and rodents DHEA is produced within the central nervous system and in peripheral nerves (Baulieu, 1998).

Cortisol stimulates the mobilization of the energy needed to overcome stressors; DHEA and DHEA-S are androgen precursors that have been shown to exert antioxidative and anti-inflammatory effects (Kalimi et al., 1994; Maninger et al., 2009) and to play a protective and regenerative role (Maninger et al., 2009; Theorell, 2009).

In humans, an acute psychosocial stress induces a DHEA and DHEA-S increase (Izawa et al., 2008; Lennartsson et al., 2012), whereas long-term psychosocial stress negatively affects both steroids levels (Izawa et al., 2012; Lennartsson et al., 2013). Elevated levels of DHEA and DHEA-S in response to the stressor have been found in both men and women, along with significantly increased ACTH, cortisol, heart rate, and blood pressure. Modifications in DHEA release in response to stressors have been observed also in the bovine species. A $23 \%$ decrease in serum DHEA and $65 \%$ higher 
cortisol:DHEA ratio were observed in lame cows compared with sound cows (Almeida et al., 2008), and a 1.6-fold DHEA decrease was observed in the plasma of transportation-stressed bulls (Sporer et al., 2008).

In cows, as in most nonprimate mammals, circulating DHEA-S is significantly lower than DHEA, which can be considered an indicator of the P450c17 enzyme activity and the most important circulating precursor of ectopic androgen and estrogen synthesis. Conversely, DHEA-S contribution as an androgen reservoir is rather limited (Feher et al., 1977; Marinelli et al., 2007). In the bovine, DHEA concentrations are quite variable between individuals in both female (Marinelli et al., 2007) and male (Simontacchi et al., 2004) animals.

Increased stocking density is a common practice among dairy producers; the behavioral consequences of this practice are well documented, whereas the physiological ones have still not been thoroughly investigated. Fregonesi et al. (2007a) observed in dairy cows a linear reduction in lying time as freestall stocking density increased, whereas Huzzey et al. (2006) observed a linear reduction in feeding time as stocking density at the feed bunk was increased. Moreover, increased aggressive displacements are often observed at the overstocked feed bunk or freestalls (Huzzey et al., 2006; Fregonesi et al., 2007b); these competitive environments can make it difficult for some cows to gain access to feed. As for the physiological consequences of overstocking, previous works have shown that cows regrouped into a high stocking density group (Friend et al., 1977) or subjected to overcrowding in the resting area (Friend et al., 1979) presented a higher cortisol response to ACTH challenge compared with cows that were not regrouped or overcrowded, respectively.

In contrast to cortisol, DHEA and DHEA-S have received little attention within the stress research area of domestic animals and no studies so far have investigated the effect of overcrowding on DHEA secretion.

Therefore, the aim of this study was to verify whether overstocking during the dry period affects DHEA and cortisol secretion and the behaviors of activity, rumination, resting, and lying time in Holstein Friesian cows.

\section{MATERIALS AND METHODS}

\section{Animals, Housing, and Diet}

Twenty-eight Holstein dairy cows were enrolled in this experiment. All animals were housed at the farm of the University of Bologna (Ozzano Emilia, Italy) and used according to EEC animal care guidelines. The experimental procedures had been approved by the Ethical Committee of Bologna University.
Animals were randomly divided into 2 groups (14 animals each), balanced for number of lactations (1.35 $\pm 1.31)$, BCS $(3.58 \pm 0.35)$, and expected date of calving. Cows in the far-off phase of the dry period (60 to $21 \mathrm{~d}$ before the expected calving date) were housed together in a bedded pack and received water and grass hay ad libitum. From $21 \pm 3$ d until calving, animals were housed in 2 bedded-pack groups where they had ad libitum access to water and were fed daily using TMR. After calving, cows were housed together in a bedded pack area for the first 2 wk of lactation and then moved to a freestall pen in a group composed of 20 cows overall for the rest of lactation. The TMR were fed approximately at $0700 \mathrm{~h}$ for lactating cows and $0900 \mathrm{~h}$ for dry cows. The TMR samples were collected weekly throughout the study and analyzed for the chemical composition according to the following methods: DM was determined by gravimetrically drying the sample at $103^{\circ} \mathrm{C}$ to a constant weight, and $\mathrm{CP}$, amylase- and sodium sulfite-treated NDF with ash correction (aNDFom), ADF, and ADL were determined according to Mertens (2002), and AOAC 973.18 (AOAC, 1990), respectively. Starch was determined according to AOAC (1990) method 996.11 and ether extract according to method 920.390020. Diet composition and analysis for both dry period and lactation are shown in Table 1.

\section{Experimental Design, Blood Sampling, and Hormone Assays}

Animals from $21 \mathrm{~d}$ before the expected calving until calving were housed in pens with the same size $(24.0$ $\mathrm{m}^{2}$ in total with $15.5 \mathrm{~m}^{2}$ of resting area and $8.5 \mathrm{~m}^{2}$ of feeding area) but in different crowding conditions due to the introduction of heifers into the pen (interference animals) having a BW of 500 to $550 \mathrm{~kg}$. In particular, the control condition (CTR) had 2 animals per pen with $12.0 \mathrm{~m}^{2}$ each, whereas the overstocked condition (OS) had 3 interference animals in the same pen with $4.8 \mathrm{~m}^{2}$ for each animal. Interference animals were part of the group during the far-off dry period, to avoid social stress at the introduction. Bunk space was $3.3 \mathrm{~m}$ long and designed with a neck rail allowing a space of $1.65 \mathrm{~m} /$ head for each CTR animal and $0.66 \mathrm{~m} /$ head for each OS animal. Resting area was a deep-bedded pack with straw added twice a day.

On $\mathrm{d}-30 \pm 3,-21 \pm 3,-15 \pm 3,-10 \pm 3,-5 \pm 3$ before and 10, 20, and $30 \mathrm{~d}$ after calving, blood samples were collected from each cow from a jugular vein for the determination of plasma DHEA and cortisol concentrations. Blood samples were collected before the morning feeding while cows were restrained in individual 
Table 1. Ingredients and chemical composition of the rations

\begin{tabular}{|c|c|c|}
\hline Composition & $\begin{array}{l}\text { TMR dry } \\
\text { period }\end{array}$ & $\begin{array}{c}\text { TMR } \\
\text { lactation }\end{array}$ \\
\hline \multicolumn{3}{|l|}{ Ingredient $(\%$ of $\mathrm{DM})$} \\
\hline Grass hay ${ }^{1}$ & 71.0 & 48.6 \\
\hline Corn ground fine & - & 20.0 \\
\hline Sorghum grain meal & - & 16.5 \\
\hline Soybean meal & - & 7.9 \\
\hline Molasses & - & 0.5 \\
\hline Concentrate $\operatorname{mix}^{2}$ & 29.0 & - \\
\hline Vitamins and minerals ${ }^{3}$ & - & 1.7 \\
\hline \multicolumn{3}{|c|}{ Chemical composition (\% of DM) } \\
\hline $\mathrm{CP}$ & 12.4 & 14.1 \\
\hline aNDFom & 44.7 & 33.5 \\
\hline $\mathrm{ADF}$ & 31.5 & 19.9 \\
\hline ADL & 5.8 & 4.1 \\
\hline Starch & 11.1 & 23.7 \\
\hline Ether extract & 3.3 & 3.5 \\
\hline Ash & 5.6 & 6.7 \\
\hline $\mathrm{NE}_{\mathrm{L}}(\mathrm{Mcal} / \mathrm{kg}$ of $\mathrm{DM})$ & 1.5 & 1.7 \\
\hline
\end{tabular}

${ }^{1}$ Grass hay chemical composition on a DM basis was $8.9 \%$ CP, $54 \%$ amylase- and sodium sulfite-treated NDF with ash correction (aNDFom), 39.9\% ADF, 7.5\% ADL, and $8.8 \%$ ash.

${ }^{2}$ Concentrate mix: $48 \%$ corn meal, $20 \%$ soybean meal, $15 \%$ wheat bran, $10 \%$ beet pulp, $5 \%$ sunflower meal, $2 \%$ mineral mix $(4 \% \mathrm{Ca}, 6 \%$ $\mathrm{P}, 4 \% \mathrm{Na}, 10 \% \mathrm{Mg}, 2,000 \mathrm{mg} / \mathrm{kg}$ of Zn, $1,500 \mathrm{mg} / \mathrm{kg}$ of Fe, $1,000 \mathrm{mg} /$ $\mathrm{kg}$ of $\mathrm{Mn}, 175 \mathrm{mg} / \mathrm{kg}$ of Cu, $150 \mathrm{mg} / \mathrm{kg}$ of I, $30 \mathrm{mg} / \mathrm{kg}$ of Se, 2,000,000 $\mathrm{IU} / \mathrm{kg}$ of vitamin $\mathrm{A}, 60,000 \mathrm{IU} / \mathrm{kg}$ of vitamin $\mathrm{D}_{3}$, and $10,000 \mathrm{mg} / \mathrm{kg}$ of vitamin E).

${ }^{3}$ The vitamin and mineral supplement for lactating cows contained $1.4 \% \mathrm{Ca}, 8.3 \% \mathrm{P}, 16 \% \mathrm{Na}, 5.5 \% \mathrm{Mg}, 4,000 \mathrm{mg} / \mathrm{kg}$ of $\mathrm{Zn}, 4,000 \mathrm{mg} / \mathrm{kg}$ of Mn, $400 \mathrm{mg} / \mathrm{kg}$ of Cu, $400 \mathrm{mg} / \mathrm{kg}$ of I, $40 \mathrm{mg} / \mathrm{kg}$ of Se, $20 \mathrm{mg} / \mathrm{kg}$ of Co, $1,200,000 \mathrm{IU} / \mathrm{kg}$ of vitamin $\mathrm{A}, 200,000 \mathrm{IU} / \mathrm{kg}$ of vitamin $\mathrm{D}_{3}$, and $1,000 \mathrm{mg} / \mathrm{kg}$ of vitamin $\mathrm{E}$.

self-locking headlocks adjacent to the feed bunk. The needles used were 20 gauge and samples were collected into evacuated heparinized tubes. The utmost care was taken to minimize stress during sample collection.

After collection, blood samples were placed immediately on ice and centrifuged at $1,200 \times g$ for $20 \mathrm{~min}$ at $4^{\circ} \mathrm{C}$. Plasma was harvested and stored at $-20^{\circ} \mathrm{C}$ until steroids were measured. Plasma cortisol concentration was determined using a validated RIA as previously described (Tamanini et al., 1983). The sensitivity of the assay was $4.3 \mathrm{pg} /$ tube, and the intra- and interassay coefficients of variation were 5.4 and $8.6 \%$, respectively. Cortisol plasma levels are expressed as nanograms per milliliter.

Plasma DHEA was measured by a microtiter RIA method previously described (Gabai et al., 2004), using a commercial anti-DHEA-7-carboxymethyloxime-BSA (Biogenesis, Poole, UK) that showed the following crossreactions: DHEA 100\%, $5 \alpha$-androstane- $3 \beta, 17 \beta$-diol $6.3 \%$, androstenedione $1.3 \%$, testosterone $0.1 \%$, and other related compounds less than $0.05 \%$. The antiserum was used at a working dilution of 1:20,000. The tracer was $[1,3,6,7$ 3H]DHEA (Perkin-Elmer Life Sciences, Waltham, MA; specific activity: $71 \mathrm{Ci} / \mathrm{mmol}$;
$30 \mathrm{pg} /$ well). The standard curve was made by serially diluting (1.56-200 pg/well) a solution of DHEA (Sigma, Milan, Italy). The detection limit of the assay was $1.56 \mathrm{pg} /$ well (software Riasmart; Perkin-Elmer Life Sciences). The results of the intra- and interassay precision test, expressed as coefficients of variation, were 3.7 and $7.2 \%$, respectively.

\section{Body Condition Score}

At enrolment ( $60 \mathrm{~d}$ before calving), 3 wk before calving, calving, and 5 wk of lactation, all cows were scored for body condition $(1=$ emaciated and $5=$ obese; 0.25-unit increments, as described by Edmonson et al., 1989) and locomotion $(1=$ normal locomotion and $5=$ severely lame, as described by Sprecher et al., 1997). Cows with locomotion score $\geq 3$ were considered lame. Body condition score and locomotion score were performed by the same observer for the whole experiment to avoid inter-observer variability.

\section{Behavior Monitoring}

Rumination time was recorded using the Hi-Tag rumination monitoring system (SCR Engineers Ltd., Netanya, Israel). This rumination sensor included a microphone that detects rumination sounds, a motion sensor, a microprocessor, a storage unit, and a battery. The sensor was fixed on a collar and placed on the left side of the cow's neck. To guarantee the correct position of the tag, a counter weight was placed on the bottom of the collar. The data were sent to a $\mathrm{PC}$ via antenna. Software (Data Flow software, SCR Engineers Ltd.) analyzed the rumination time as minutes of $2 \mathrm{~h}$ (Schirmann et al., 2009) and calculated the rumination time of the last $24 \mathrm{~h}$.

The cows were also equipped with another sensor (Pedometer Plus; S.A.E. Afikim) that monitored 3 parameters: activity (steps/h), lying time $(\mathrm{min} / \mathrm{d})$, and lying bouts (switching between standing and lying; Higginson et al., 2009). The tag was attached to a leg band on the right rear leg of each cow and the data were accumulated and transmitted to management software (AfiFarm; S.A.E. Afikim) each time the cows passed an antenna located in the milking parlor and under the water troughs. Behavioral data were collected every day but for statistical analysis the data were averaged per week.

\section{Clinical Examination and Definitions of Diseases}

All cows were examined at 1, 3, and 10 DIM for diagnosis of retained fetal membrane, metritis, and 
acute metritis. Retained fetal membrane was defined as retention of fetal membrane after $24 \mathrm{~h}$ postpartum. Metritis was defined as cows with watery, pink or brown, and fetid uterine discharge. Cows with symptoms of metritis, rectal temperature $>39.5^{\circ} \mathrm{C}$, or anorectic, or depressed were considered to have acute metritis (Sheldon et al., 2006). All cows were observed once daily for displacement of abomasum and twice daily for mastitis throughout their lactation.

\section{Production Parameters}

After calving, cows were milked twice daily at 0730 and $1930 \mathrm{~h}$ and individual yield of milk (AfiFlo milk meters, S.A.E. Afikim), concentrations of fat, true protein, and lactose (AfiLab on-line real-time milk analyzer, S.A.E. Afikim) were recorded by the Afikim milking system. The AfiLab system is calibrated once monthly with data on milk composition from 90 cows analyzed by the ARAER Laboratory (Modena, Italy). Concentrations of milk components from each milking were used to calculate the daily yields of fat, protein, and lactose after adjusting for milk production during each milking. The ECM yield was calculated as $[(0.327$ $\times$ milk yield $)+(12.95 \times$ fat yield $)+(7.2 \times$ protein yield)] (Orth, 1992). Daily values were averaged into weekly means for statistical analyses.

\section{Statistical Analysis}

The experiment had a randomized switch-back design with pen as the experimental unit. Seven replicates were used, 6 of them had a pregnant heifer (nulliparous animal) and a cow (parous animal) together, and one replicate had only cows. All statistical analyses were conducted using SAS version 9.2 (SAS/STAT, SAS Institute Inc., Cary, NC). Data were tested for nonnormality by using the Shapiro test. Binomial dependent variables were analyzed by logistic regression using GLIMMIX procedure with a binary distribution. Continuous data were analyzed by ANOVA for repeated measures using the MIXED procedure. The structure of covariance (autoregressive, unstructured, or compound symmetry) was chosen according to the Bayesian Akaike information criteria. In all models, treatment (OS vs. CTR), replicate (1 to 7 ), and parity (nulliparous vs. parous) were included as fixed effects. For analysis of repeated measurement variables, time and the interaction between treatment and time were included in the model as fixed effects. Only the independent variables with $P<0.10$ were retained in the model. Cortisol data were handled by log-transformation to match normality.

\section{RESULTS AND DISCUSSION}

To our knowledge, this is the first study that demonstrates the difference in time-course variation of DHEA and cortisol secretion in response to overstocking during the dry period in Holstein Friesian cows. In both groups, before calving, an increase in DHEA was observed, which tended to be more evident in the overstocked group, although the difference between groups was significant only at $-10 \mathrm{~d}$. Then, DHEA concentrations rapidly declined after parturition. Overstocking significantly $(P=0.0049)$ increased DHEA concentration compared with the CTR group at $\mathrm{d}-10(1.79 \pm$ 0.09 vs. $1.24 \pm 0.14 \mathrm{pmol} / \mathrm{mL})$, whereas an increase of cortisol was observed $(P=0.022)$ at $\mathrm{d}-15(3.64 \pm 0.52$ vs. $1.64 \pm 0.46 \mathrm{ng} / \mathrm{mL}$; Figure 1). No correlation was found between DHEA and cortisol.

In primates and rodents, it is generally accepted that DHEA is secreted mainly by the adrenal cortex and the ovary (Baulieu, 1998), and peripheral tissues are able to metabolize this steroid into active androgens and estrogens (Labrie, 1991). In pregnant primates and horses, placenta can use circulating DHEA to synthesize estrogens (Strauss et al., 1996).

In humans, DHEA and DHEA-S levels significantly increase in response to acute psychological stress (Lennartsson et al., 2012) and it has been suggested that these steroids play a protective role during the stress reaction, antagonizing the effects of cortisol (Hechter et al., 1997; Morgan et al., 2004). The stress-induced DHEA and DHEA-S increase has likely behavioral and emotional effects. Studies on mice showed antidepressant, anxiolytic, anti-aggression, and memory-enhancing effects of DHEA-S (Melchior and Ritzmann, 1994).

In cattle, stressful situations are associated with a decrease in circulating DHEA, as suggested by observations in lame cows (Almeida et al., 2008) and in transportation-stressed bulls (Sporer et al., 2008). In the late pregnant cow, Marinelli et al. (2007) suggested that the placenta is the most important source of DHEA; the placenta mainly uses the $\Delta 5$ steroidogenic pathway to produce estrogen (Geisert and Conley, 1998). Previous works (Gabai et al., 2004; Marinelli et al., 2007) indicate that the DHEA placental secretion increases in late pregnancy, probably depending upon the tissue mass (Geisert and Conley, 1998), and suddenly decreases after parturition. Therefore, the DHEA increase observed in the OS group approximately $5 \mathrm{~d}$ following a significant increase in plasma cortisol was surprising. Indeed, adrenal DHEA has been reported being secreted synchronously with cortisol during night and day (Rosenfeld et al., 1971), and the delay in DHEA secretion in respect to cortisol was unexpected. A pos- 
sible explanation resides in the stimulating glucocorticoid effect on the placental CYP17 enzyme in the cow (Gross and Williams, 1988; Shenavai et al., 2012) that, in turn, could speed up the conversion of pregnenolone into DHEA.

Walking is associated with an increase in plasma cortisol concentrations (Coulon et al., 1998) and, likely, the OS cows, which displayed the greater number of steps per hour and thus were more active, experienced higher cortisol concentrations during the prepartum period, possibly resulting in the higher cortisol concentrations observed on $\mathrm{d}-15$. The suitability of blood cortisol as a stress biomarker in livestock is in doubt because of its variability and blood sampling is an invasive technique that can cause the activation of the hypothalamicpituitary-adrenal (HPA) axis (Mormede et al., 2007). Therefore, the intrinsic variability in plasma cortisol could have masked the greater HPA activation associated with OS and increased walking. Moreover, it is possible that the cows' HPA axis responded to increased walking during the first day of the OS treatment and then animals adapted. Indeed, Coulon et al. (1998) observed that cortisol concentrations were higher on d 1 and 8 in cows that walked compared with cows that remained at the barn, but the difference was not evident after 20 d. A recent study conducted by Silva et al. (2016) evaluated the effects of prepartum stocking density on serum cortisol and hair cortisol concentra-
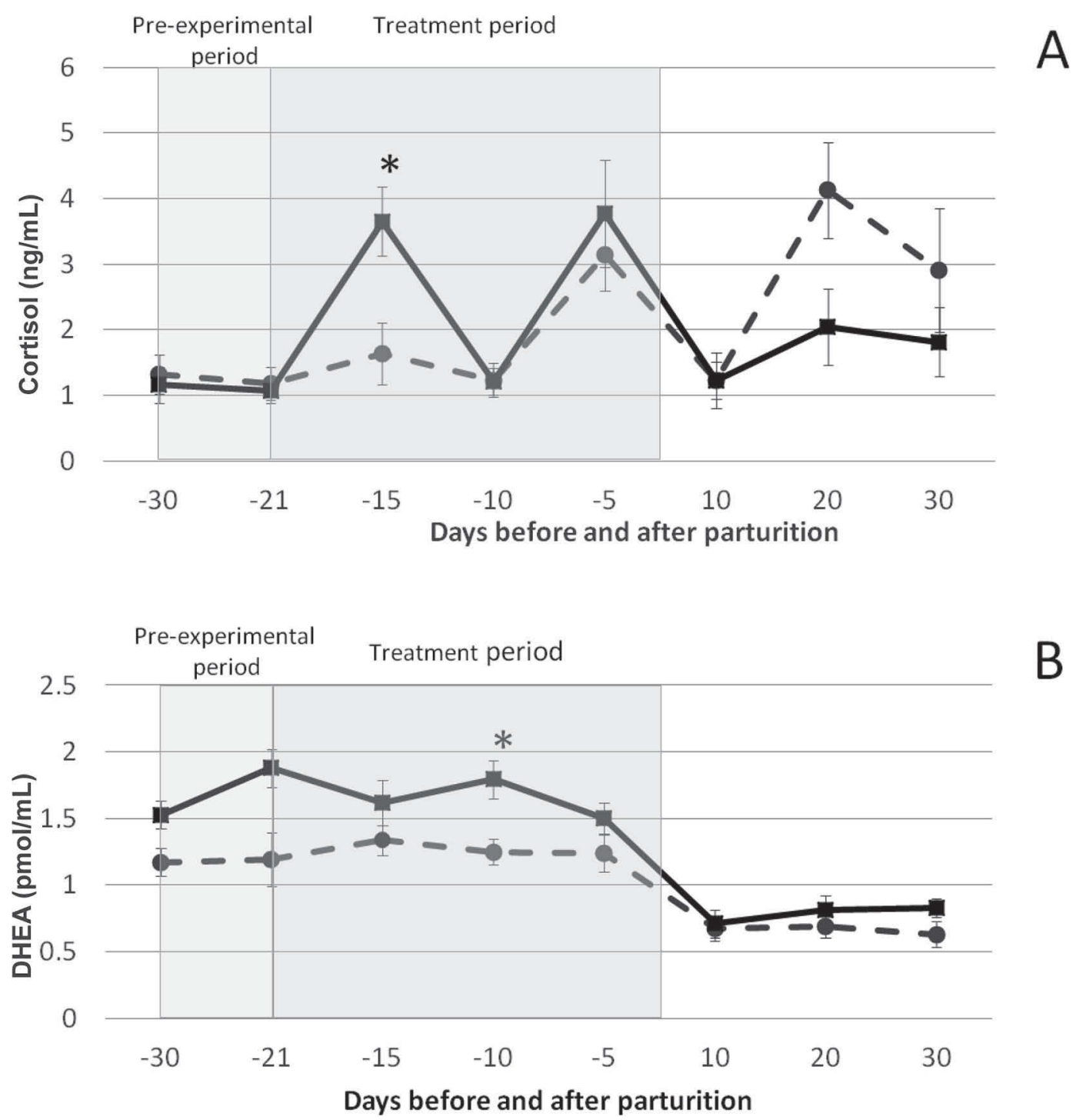

Figure 1. Plasma cortisol and dehydroepiandrosterone (DHEA) concentrations in control (CTR; $\bullet$ ) and overstocked condition (OS; group over the transition period. The asterisk indicates a statistically significant difference between the CTR and OS $(P<0.05)$ group. Values are mean \pm SEM. 
Table 2. Mean ruminating period (total min/d) and mean activity (steps/h) in response to treatment over the transition period: wk -4 is the pre-experimental period, wk -3 to -1 is the treatment period, wk 1 to 2 is housed in bedded packed area, wk 3 to 4 is housed in a freestall barn

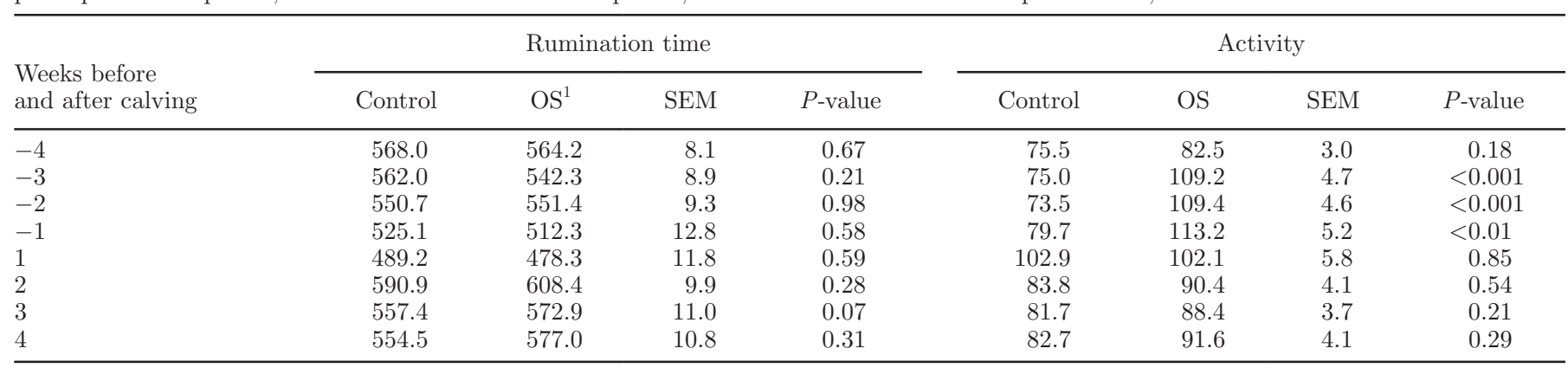

${ }^{1} \mathrm{OS}=$ overstocked condition.

tion of Jersey cows. Treatments consisted of 80 or $100 \%$ headlock stocking density. In this study, serum and hair cortisol concentrations were not affected by treatment.

As glucocorticoids can alter placental steroidogenesis (Gross and Williams, 1988; Shenavai et al., 2012), it is possible that the modified endocrine milieu affects pregnancy length. However, in this experiment the increased plasma DHEA observed in OS cows was not associated with differences in pregnancy length [CTR $=279.9 \pm 5.0 \mathrm{~d}, \mathrm{OS}=278.7 \pm 4.2 \mathrm{~d}($ mean $\pm \mathrm{SD}) ; P$ $=0.32]$, although days dry tended to be lower for OS animals $(\mathrm{CTR}=55.6 \pm 12.6 \mathrm{~d}$, OS $=48.6 \pm 3.0 \mathrm{~d})$. At the beginning of the experimental period, days of gestation $(\mathrm{CTR}=258.8 \pm 5.3 \mathrm{~d}, \mathrm{OS}=257.7 \pm 4.7 \mathrm{~d}$; $P=0.35)$ were not different among treatments.

No major differences were found in calving difficulties. Calf weights were not different $(P=0.46)$ among treatments $(\mathrm{CTR}=41.5 \pm 3.7 \mathrm{~d}, \mathrm{OS}=41.7 \pm 4.3 \mathrm{~d})$, and no animals carried twins. Overall incidence of peripartum diseases was not different between CTR and OS treatments. No animals has displaced abomasum and mastitis in the first $5 \mathrm{wk}$ after calving. One cow had metritis in the OS group, whereas no cows in CTR group had metritis. Body condition score and lameness score were not affected by treatment. Current recommendations for feed bunk space for prepartum freestallhoused dry cows is to provide a minimum of $0.76 \mathrm{~m}$ of linear bunk space per cow (Nordlund et al., 2006). In the present study, control cows had $1.2 \mathrm{~m}$ of bunk space per cow and OS cows had only $0.66 \mathrm{~m}$ of bunk space. Reducing linear feeding space has been observed to increase competition at the feed bunk (Huzzey et al., 2006; Collings et al., 2011). However, the results of these studies, while showing more cow displacements from the feed bunk, have variable effects on feeding behavior (Collings et al., 2011; Huzzey et al., 2012). In a study on lactating cows, a reduction in feeding time was observed in multiparous cows (Proudfoot et al., 2009), and in other studies, the competitively fed cows had fewer meals per day with a tendency of larger and longer meals (Olofsson, 1999; Hosseinkhani et al., 2008). Olofsson (1999) found that competition slightly increased the DMI of dairy cows, and this increase was driven by an increase in feeding rate. Based on these studies, it is not surprising to have little or no effect on DMI with the feed bunk restriction used in the current study.

Rumination times were not different in OS animals in the current analysis (Table 2). This parameter can be a key indicator of DMI, therefore animals in both groups had similar rumen activities and more than likely similar intakes.

Total minutes of lying time per day was not different among OS and CTR groups (Table 2). In some studies, lying time has been shown to decrease with increased stocking density (Krawczel et al., 2012; Lobeck-Luchterhand et al., 2015); however, other studies using late lactation or dry cows showed no differences (Collings et al., 2011; Huzzey et al., 2012). It is consistent that dry cows with more available time throughout the day (Grant and Albright, 2001) would have sufficient hours available to allow for a normal number of lying hours. Lying time has a higher priority than eating for cows, when these 2 behaviors are restricted (Munksgaard et al., 2005). This could explain why the resting time did not change although the space was consistently lower in OS animals $\left(3.3 \mathrm{~m}^{2}\right.$ of bedded area vs. $7.8 \mathrm{~m}^{2}$ for control animals). The time budgets of prepartum cows tend to be interrupted less than lactating dairy cows because the animals are not moved outside the pen for milking and do not have cycling activity with estrus behavior. Both groups, however, showed a daily lying time lower than the recommended $12 \mathrm{~h} / \mathrm{d}$ (Munksgaard et al., 2005). Comfort of the bedding surface could be an important factor in determining daily lying time (Fregonesi et al., 2007b). In a study with either 9 or 4.5 $\mathrm{m}^{2}$ of bedded area per cow, no difference in lying time was observed (Fregonesi and Leaver, 2002). Animals 
Table 3. Mean lying period $(\mathrm{min} / \mathrm{d})$ and mean lying bouts (bouts/d) in response to treatment over the transition period: wk -4 is the preexperimental period, wk -3 to -1 is the treatment period, wk 1 to 2 is housed in bedded packed area, wk 3 to 4 is housed in a freestall barn

\begin{tabular}{|c|c|c|c|c|c|c|c|c|}
\hline $\begin{array}{l}\text { Weeks before } \\
\text { and after calving }\end{array}$ & \multicolumn{4}{|c|}{ Mean lying period } & \multicolumn{4}{|c|}{ Mean lying bouts } \\
\hline-3 & 660.7 & 670.1 & 12.9 & 0.87 & 14.2 & 16.1 & 0.5 & 0.09 \\
\hline-2 & 672.2 & 659.9 & 19.9 & 0.54 & 14.3 & 16.0 & 0.5 & 0.2 \\
\hline-1 & 643.1 & 630.6 & 16.4 & 0.41 & 15.1 & 16.6 & 0.6 & 0.32 \\
\hline 1 & 683.9 & 688.1 & 19.7 & 0.81 & 16.6 & 17.7 & 0.5 & 0.42 \\
\hline 4 & 624.5 & 605.7 & 19.8 & 0.33 & 12.7 & 12.2 & 0.6 & 0.42 \\
\hline
\end{tabular}

${ }^{1} \mathrm{OS}=$ overstocked condition.

can better tolerate overcrowding when open pack area is present compared with the stall barn because they can lie down at the same time staying closer to one another. Using freestall type bedding, lying time linearly decreased when stocking density increased from 100 to $150 \%$ (Fregonesi et al., 2007a). In same conditions, Krawczel et al. (2012) reported that lying time was reduced for stocking densities of 131 and 142\% compared with 100 or $113 \%$.

Mean lying bouts tended to be higher in OS group the first week of overcrowding, indicating an adjustment period was occurring (Table 3). Animals had a resting time that is more disrupted, considering that the daily lying time were divided in more bouts. After this first week, the behavior was similar in OS and control animals. Competition at the feed bunk generally caused an increase in standing time in multiparous transition cows (Proudfoot et al., 2009) and in midlactation cows (Olofsson, 1999; Huzzey et al., 2006). The importance of this is determined by the overall DMI of the animals. Excessive standing time is a risk factor for developing lameness conditions such as claw horn lesions (Greenough and Vermunt, 1991; Singh et al., 1993). Avoiding excessive standing is important throughout lactation, but in particular during transition when animals are subjected to many endocrine and metabolic changes (Goff and Horst, 1997).

As for the activity behavior, the OS group showed significantly higher activity (steps/h), compared with

Table 4. Mean ECM yield $(\mathrm{kg} / \mathrm{d})$ in response to treatment over the transition period

\begin{tabular}{lcccc}
\hline $\begin{array}{l}\text { Weeks after } \\
\text { calving }\end{array}$ & Control & OS $^{1}$ & SEM & $P$-value \\
\hline 1 & 24.2 & 21.5 & 1.3 & 0.46 \\
2 & 34.8 & 32.1 & 1.6 & 0.53 \\
3 & 36.6 & 33.9 & 1.5 & 0.77 \\
4 & 38.2 & 36.9 & 1.4 & 0.65 \\
\hline
\end{tabular}

${ }^{1} \mathrm{OS}=$ overstocked condition. the CTR group, as reported in Table 2. This difference could indicate the increased need of movement in the pen and represents another evidence of stress occurring in this phase. An increased number of animal displacements and animal movement would be expected with overcrowding and feed bunk restriction (Collings et al., 2011; Huzzey et al., 2012) and the related stress could be expected to alter parameters being measured in this study.

Energy-corrected milk production was not different among treatments (Table 4). Among cows, treatment did not differ regarding previous lactation 305-d mature-equivalent milk yield $(\mathrm{CTR}=10.2 \pm 231.1 \mathrm{~kg}$, OS $=10.0 \pm 191.7 \mathrm{~kg} ; P=0.39)$ so we can assume that no interference effect of the genetic potential was present. A recent study (Silva et al., 2014) reported no difference in yield of ECM when cows were overcrowded. It would be expected that the minimal differences in cow behavior and rumination, as observed in this study, would not carry through to any differences in DMI or early lactation milk production.

The overall results of this study documented that overstocking during the dry period is associated with short-term changes in DHEA and cortisol but these hormonal modifications do not influence cow behavior.

\section{ACKNOWLEDGMENTS}

This work was supported by a MIUR grant (Grant of Italian Ministry of Instruction, University and Research; prot. 2010YBP4LZ_003). We thank Laura Da Dalt (University of Padova, Padua, Legnaro, Italy) and Sara Speroni (University of Bologna, Bologna, Italy) for skilled technical assistance.

\section{REFERENCES}

Almeida, P. E., P. S. D. Weber, J. L. Burton, and A. J. Zanella. 2008. Depressed DHEA and increased sickness response behaviors 
in lame dairy cows with inflammatory foot lesions. Domest. Anim. Endocrinol. 34:89-99.

AOAC. 1990. Official Methods of Analysis. 15th ed. AOAC, Arlington, VA.

Baulieu, E. E. 1998. Neurosteroids: A novel function of the brain. Psychoneuroendocrinology 23:963-987.

Collings, L. K., D. M. Weary, N. Chapinal, and M. A. von Keyserlingk. 2011. Temporal feed restriction and overstocking increase competition for feed by dairy cattle. J. Dairy Sci. 94:5480-5486.

Coulon, J. B., P. Pradel, T. Cochard, and B. Poutrel. 1998. Effect of extreme walking conditions for dairy cows on milk yield, chemical composition, and somatic cell count. J. Dairy Sci. 81:994-1003.

Edmonson, A. J., I. J. Lean, L. D. Weaver, T. Farver, and G. Webster. 1989. A body condition scoring chart for Holstein dairy cows. J. Dairy Sci. 72:68-78.

Feher, T., L. Bodrogi, K. G. Feher, E. Poteczin, and I. S. Kolcsey. 1977. Free and solvolysable dehydroepiandrosterone and androsterone in blood of mammals under physiological conditions and following administration of dehydroepiandrosterone. Acta Endocrinol. (Copenh.) 85:126-133.

Fregonesi, J. A., and J. D. Leaver. 2002. Influence of space allowance and milk yield level on behaviour, performance and health of dairy cows housed in strawyard and cubicle systems. Livest. Prod. Sci. $78: 245-257$.

Fregonesi, J. A., C. B. Tucker, and D. M. Weary. 2007a. Overstocking reduces lying time in dairy cows. J. Dairy Sci. 90:3349-3354.

Fregonesi, J. A., D. M. Veira, M. A. G. von Keyserlingk, and D. M. Weary. 2007b. Effects of bedding quality on lying behavior of dairy cows. J. Dairy Sci. 90:5468-5472.

Friend, T. H., F. C. Gwazdauskas, and C. E. Polan. 1979. Change in adrenal response from free stall competition. J. Dairy Sci. 62:768 771.

Friend, T. H., C. E. Polan, F. C. Gwazdauskas, and C. W. Heald. 1977. Adrenal glucocorticoid response to exogenous adrenocorticotropin mediated by density and social disruption in lactating cows. J. Dairy Sci. 60:1958-1963.

Gabai, G., L. Marinelli, C. Simontacchi, and G. Bono. 2004. The increase of plasma C195 steroids in subcutaneous abdominal and jugular veins of dairy cattle during pregnancy is unrelated to estrogenic activity. Steroids 69:121-127.

Geisert, R. D., and A. J. Conley. 1998. Secretion and metabolism of steroids in subprimate mammals during pregnancy. Pages 291-318 in The Endocrinology of Pregnancy. F. W. Bazer and P. M. Conn, ed. Humana Press Inc., Totowa, NJ.

Goff, J. P., and R. L. Horst. 1997. Physiological changes at parturition and their relationships to metabolic disorders. J. Dairy Sci. 80:1260-1268.

Grant, R. J., and J. L. Albright. 2001. Effect of animal grouping on feeding behaviour and intake of dairy cattle. J. Dairy Sci. 84:156163.

Greenough, P. R., and J. J. Vermunt. 1991. Evaluation of subclinical laminitis in a dairy herd and observations on associated nutritional and management factors. Vet. Rec. 128:11-17.

Gross, T. S., and W. F. Williams. 1988. In vitro steroid synthesis by the placenta of cows in late gestation and at parturition. J. Reprod. Fertil. 83:565-573.

Hechter, O., A. Grossman, and R. T. Chatterton Jr.. 1997. Relationship of dehydroepiandrosterone and cortisol in disease. Med. Hypotheses 49:85-91.

Higginson, J. H., K. E. Leslie, S. T. Millman, and D. F. Kelton. 2009. Evaluation of the Pedometry Plus system for the detection of pedometric activity and lying behaviour in dairy cattle. J. Dairy. Sci. 92(E-Suppl. 1):346.

Hosseinkhani, A., T. J. DeVries, K. L. Proudfoot, R. Valizadeh, D M. Veira, and M. A. G. von Keyserlingk. 2008. The effects of feed bunk competition on the feed sorting behavior of close-up dry cows. J. Dairy Sci. 91:1115-1121.

Huzzey, J. M., T. J. DeVries, P. Valois, and M. A. G. von Keyserlingk. 2006. Stocking density and feed barrier design affect the feeding and social behavior of dairy cattle. J. Dairy Sci. 89:126-133.
Huzzey, J. M., D. V. Nydam, R. J. Grant, and T. R. Overton. 2012. The effects of overstocking Holstein dairy cattle during the dry period on cortisol secretion and energy metabolism. J. Dairy Sci. 95:4421-4433.

Izawa, S., K. Saito, K. Shirotsuki, N. Sugaya, and S. Nomura. 2012. Effects of prolonged stress on salivary cortisol and dehydroepiandrosterone: A study of a two-week teaching practice. Psychoneuroendocrinology 37:852-858.

Izawa, S., N. Sugaya, K. Shirotsuki, K. C. Yamada, N. Ogawa, Y. Ouchi, Y. Nagano, K. Suzuki, and S. Nomura. 2008. Salivary dehydroepiandrosterone secretion in response to acute psychosocial stress and its correlations with biological and psychological changes. Biol. Psychol. 79:294-298.

Kalimi, M., Y. Shafagoj, R. Loria, D. Padgett, and W. Regelson. 1994 Anti-glucocorticoid effects of dehydroepiandrosterone (DHEA). Mol. Cell. Biochem. 131:99-104.

Krawczel, P. D., L. B. Klaiber, R. E. Butzler, L. M. Klaiber, H. M. Dann, C. S. Mooney, and R. J. Grant. 2012. Short-term increases in stocking density affect the lying and social behavior, but not the productivity, of lactating Holstein dairy cows. J. Dairy Sci. 95:4298-4308

Labrie, F. 1991. At the cutting edge: Intracrinology. Mol. Cell. Endocrinol. 78:C113-C118.

Lennartsson, A. K., M. M. Kushnir, J. Bergquist, and I. H. Jonsdottir. 2012. DHEA and DHEA-S response to acute psychosocial stress in healthy men and women. Biol. Psychol. 90:143-149.

Lennartsson, A. K., T. Theorell, M. M. Kushnir, J. Bergquist, and I. H. Jonsdottir. 2013. Perceived stress at work is associated with attenuated DHEA-S response during acute psychosocial stress. Psychoneuroendocrinology 38:1650-1657.

Lobeck-Luchterhand, K. M., P. R. Silva, R. C. Chebel, and M. I. Endres. 2015. Effect of stocking density on social, feeding, and lying behavior of prepartum dairy animals. J. Dairy Sci. 98:240-249.

Maninger, N., O. M. Wolkowitz, V. I. Reus, E. S. Epel, and S. H. Mellon. 2009. Neurobiological and neuropsychiatric effects of dehydroepiandrosterone (DHEA) and DHEA sulfate (DHEAS). Front. Neuroendocrinol. 30:65-91.

Marinelli, L., E. Trevisi, L. Da Dalt, M. Merlo, G. Bertoni, and G. Gabai. 2007. Dehydroepiandrosterone secretion in dairy cattle is episodic and unaffected by ACTH stimulation. J. Endocrinol. 194:627-635.

Melchior, C. L., and R. F. Ritzmann. 1994. Dehydroepiandrosterone is an anxiolytic in mice on the plus maze. Pharmacol. Biochem. Behav. 47:437-441.

Mertens, D. R. 2002. Gravimetric determination of amylase-treated neutral detergent fiber in feeds with refluxing in beakers or crucibles: Collaborative study. J. AOAC Int. 85:1217-1240.

Morgan, C. A. 3rd, S. Southwick, G. Hazlett, A. Rasmusson, G. Hoyt, Z. Zimolo, and D. Charney. 2004. Relationships among plasma dehydroepiandrosterone sulfate and cortisol levels, symptoms of dissociation, and objective performance in humans exposed to acute stress. Arch. Gen. Psychiatry 61:819-825.

Mormede, P., S. Andanson, B. Auperin, B. Beerda, D. Guemene, J. Mamkvist, X. Manteca, G. Manteuffel, P. Prunet, C. G. van Reenen, S. Richard, and I. Veissier. 2007. Exploration of the hypothalamic-pituitary-adrenal function as a tool to evaluate animal welfare. Physiol. Behav. 92:317-339.

Munksgaard, L., M. B. Jensen, L. J. Pedersen, S. W. Hansen, and L. Matthews. 2005. Quantifying behavioural priorities - Effects of time constraints on behaviour of dairy cows, Bos taurus. Appl. Anim. Behav. Sci. 92:3-14.

Nguyen, A. D., and A. J. Conley. 2008. Adrenal androgens in humans and nonhuman primates: Production, zonation and regulation. Endocr. Dev. 13:33-54.

Nordlund, K., N. Cook, and G. Oetzel. 2006. Commingling dairy cows: Pen moves, stocking density, and health. Pages 36-42 in 39th Proc. Am. Assoc. Bovine Pract., St. Paul, MN. Bovine Practitioner, Opelika, AL.

Olofsson, J. 1999. Competition for total mixed diets fed for ad libitum intake using one or four cows per feeding station. J. Dairy Sci 82:69-79. 
Orth, R. 1992. Sample Day and Lactation Report. DHIA 200 Fact Sheet A-2. Mid-States DRPC, Ames, IA.

Proudfoot, K. L., D. M. Veira, D. M. Weary, and M. A. G. von Keyserlingk. 2009. Competition at the feed bunk changes the feeding, standing and social behavior of transition dairy cows. J. Dairy Sci. 92:3116-3123.

Rosenfeld, R. S., L. Hellman, H. Roffwarg, E. D. Weitzman, D. K. Fukushima, and T. F. Gallagher. 1971. Dehydroisoandrosterone is secreted episodically and synchronously with cortisol by normal man. J. Clin. Endocrinol. Metab. 33:87-92.

Schirmann, K., M. A. G. von Keyserlingk, D. M. Weary, D. M. Veira, and W. Heuwieser. 2009. Technical note: Validation of a system for monitoring rumination in dairy cows. J. Dairy Sci. 92:6052-6055.

Sheldon, I. M., G. S. Lewis, S. LeBlanc, and R. O. Gilbert. 2006 Defining postpartum uterine disease in cattle. Theriogenology 65:1516-1530.

Shenavai, S., S. Preissing, B. Hoffmann, M. Dilly, C. Pfarrer, C. G. Ozalp, C. Caliskan, K. Seyrek-Intas, and G. Schuler. 2012. Investigations into the mechanisms controlling parturition in cattle. Reproduction 144:279-292.

Silva, P. R. B., A. R. Dresch, K. S. Machado, J. G. N. Moraes, K. Lobeck-Luchterhand, T. K. Nishimura, M. A. Ferreira, M. I. Endres, and R. C. Chebel. 2014. Prepartum stocking density: Effects on metabolic, health, reproductive, and productive responses. J. Dairy Sci. 97:5521-5532.

Silva, P. R. B., K. M. Lobeck-Luchterhand, R. L. A. Cerri, D. M. Haines, M. A. Ballou, M. I. Endres, and R. C. Chebel. 2016. Effects of prepartum stocking density on innate and adaptive leukocyte responses and serum and hair cortisol concentrations. Vet. Immunol. Immunopathol. 169:39-46.

Simontacchi, C., T. Perez de Altamirano, L. Marinelli, R. Angeletti, and G. Gabai. 2004. Plasma steroid variations in bull calves re- peatedly treated with testosterone, nortestosterone and oestradiol administered alone or in combination. Vet. Res. Commun. 28:467-477.

Singh, S. S., W. R. Ward, J. W. Lautenbach, J. W. Hughes, and R. D. Murray. 1993. Behaviour of first lactation and adult dairy cows while housed and at pasture and its relationship with sole lesions. Vet. Rec. 133:469-474.

Sirinathsinghji, D. J. S., and I. H. Mills. 1983. Effect of human pituitary luteinizing hormone administration on plasma levels of dehydroepiandrosterone, androstenediol and their sulphates and testosterone in women with secondary amenorrhea. J. Endocrinol. 98:201-210.

Sporer, K. R., L. Xiao, R. J. Tempelman, J. L. Burton, B. Earley, and M. A. Crowe. 2008. Transportation stress alters the circulating steroid environment and neutrophil gene expression in beef bulls. Vet. Immunol. Immunopathol. 121:300-320.

Sprecher, D. J., D. E. Hostetler, and J. B. Kaneene. 1997. A lameness scoring system that uses posture and gait to predict dairy cattle reproductive performance. Theriogenology 47:1179-1187.

Strauss, J. F. 3rd, F. Martinez, and M. Kiriakidou. 1996. Placental steroid hormone synthesis: Unique features and unanswered questions. Biol. Reprod. 54:303-311.

Tamanini, C., N. Giordano, F. Chiesa, and E. Seren. 1983. Plasma cortisol variations induced in the stallion by mating. Acta. Endocrinol. 102:447-450.

Theorell, T. 2009. Anabolism and catabolism. Current Perspectives on Job-Stress Recovery (Research in Occupational Stress and Well Being). S. Sonnentag, D. C. Ganster, and P. L. Perrewe, ed. $7: 249-276$ 